\title{
Carlos Esplá: anticlericalismo y masonería en un republicano español del siglo XX
}

\author{
Pedro L. Angosto Vélez
}

\begin{abstract}
RESUMEN
ABSTRACT

A través de este artículo se ha intentado

dar una explicación -dentro del

Through this article we have tried to explain - within the spanish contextcontexto español- al tradicional vínculo entre republicanismo, anticlericalismo y masonería. Para ello hemos recurrido a

analizar la trayectoria de un hombre público, Carlos Esplá, que responde plenamente al perfil esencial del republicano del primer tercio del siglo xx. Se ha querido, otra cosa es que se haya conseguido, demostrar como en muchos casos tal vinculación

no respondía tanto a cuestiones dogmáticas, como a motivaciones racionalistas o coyunturales. Es decir, buena parte de los republicanos eran anticlericales y masones, lo que no queria decir que fuesen antirreligiosos, ni tampoco que cumpliesen con los ritos y las consignas del Grande Oriente.

Ambas militancias estaban estrechamente ligadas a una coyuntura histórica específica.

PALABRAS CLAVE Anticlericalismo, masonería, republicanismo, dictadura, libertad, progreso, Iglesia Católica. the traditional link between republicanism, anticlericalism and masonry. For that reason we have resorted to analise he career of a republic man, Carlos Esplá, who perfectly answers to the profile of the republican of the first third of the $x x$ Century. We have, we don't know if we have succeeded, to show how in lots of cases such a connection doesn't have to do with dogmatic questions as much as rationalistic or current motives.

A great deal of republicans were anticlerical and masons, which didn't mean they were anti-religious, nor that they followed the rites and instructions of the Great East. Both affiliations/tendencies were closely linked to a specific historical situation.

KEY WORDS

Anticlericalism, Freemasonry, republicanism, dictatorship, freedom, progress, Catholic Church.
\end{abstract}




\section{CONTEXTO DE UNA FORMACIÓN}

Carlos Esplá nace en Alicante el 23 de junio de 1895, cuando España estaba inmersa en las luchas que darían al traste con los últimos restos de su imperio ultramarino, en ese periodo turbulento, crítico, pero enérgico a la vez, en que se cruzan la decadencia definitiva de una España y el parto doloroso y a regañadientes, al calor de los escritos de regeneracionistas, krausistas y noventayochocentistas, de la España del siglo XX, un país que a partir de este momento dedicará buena parte de sus esfuerzos a mirar hacia adentro en un ejercicio de análisis introspectivo que durará décadas.

Durante estos años finales del siglo, el republicanismo anda dividido, atomizado, diezmado, sin que ninguna de sus figuras punteras de años atrás esté en disposición de aglutinar en derredor suyo a todas las facciones. Sin embargo, como afirma Angel Duarte ', hay algo que permanece, sobreponiéndose a la crisis, en el movimiento republicano durante toda la Restauración: su infraestructura socio-cultural y su influencia en determinados sectores de la sociedad gracias a una extensa red de periódicos, tertulias, círculos, cafés, ateneos culturales, logias masónicas, sociedades espiritistas, librepensadoras, naturistas, escuelas y academias nocturnas, que, diseminadas por todo el país, marcarán su impronta en la educación y la formación de jóvenes que, como Carlos Esplá y sus compañeros de lucha: A. Pascual Leone, J. Alonso Mallol, los hermanos Botella o Lorenzo Carbonell, saltarán a la escena pública con las primeras hogueras de la Semana Trágica, cristalizando en las jornadas previas a la Segunda República, proyecto en el que invertirían lo mejor de sus vidas. A esa amalgama de organizaciones dispersas llama Duarte «canales de transmisión del republicanismo", que no eran sino una tupida red de difusión ideológica en la que se implicaban desde la familia a todo este entramado de organizaciones y sociedades con la finalidad de mantener y extender el ideal republicano? ${ }^{2}$.

En este sentido, la figura de Esplá puede ser paradigmática: tanto su familia materna como la paterna eran republicanos de viejo abolengo, destacando sobremanera su abuelo materno, Rafael Rizo, masón y amigo de Maisonnave y Carratalá, con quienes luchó codo con codo en la revolución

DuARte, A., La esperanza republicana, en CRuz, R. y PÉrez Ledesma, M., Cultura y movilización en la España contemporánea. Alianza. Madrid, 1997, págs. 182-183.

2 Ibidem. Véase: Angosto VÉlEZ, P.L., Carlos Esplá Rizo. Biografía política. Tesis Doctoral dirigida por E. La PARRA López y leída el 2 de junio de 2000 en la Universidad de Alicante. 
del 68 y en la proclamación de la Primera República en Alicante ${ }^{3}$. En el despacho de su abuelo, recordará años más tarde Carlos Esplá, había un enorme retrato de Garibaldi y objetos personales del general Prim. Su biblioteca, pequeña pero selecta, guardaba en sus anaqueles libros de obligada lectura para el buen republicano y en ellos aprendió el joven Esplá sus primeras lecciones ideológicas: "Había en aquel despacho una pequeña biblioteca... Votaire, Venot, Larra, Espronceda, Reclús, Castelar, Victor Hugo, Pérez Galdos, Pi y Margall... y viejas colecciones de periódicos revolucionarios. Frente al retrato de Garibaldi apagué la sed de saber de mis primeras lecturas. Uno de los libros que encontré fue el de las memorias de la vida de Garibaldi...» ${ }^{4}$. Además, tanto la casa de Rafael Rizo como la de sus padres eran constantemente visitadas por los republicanos más ilustres de la ciudad: Nicolás Lloret, Antonio Rico, Salvador Sellés o José Guardiola. Allí tenían lugar concurridas tertulias, que Esplá, desde niño, escuchaba en silencio. Bien pronto, el Dr. Rico, renovador del republicanismo alicantino en los primeros años del siglo $\mathrm{xx}$, filántropo, humanista, anticlerical, masón y médico de la familia, y Salvador Sellés, poeta, dramaturgo,anticlerical, masón y vicepresidente de la Asociación Española de Espiritismo, se fijaron en aquel muchacho de ojos despiertos y un tanto tímido, que cada tarde, en vez de ir a retozar con los amigos, se quedaba agazapado en un sillón oyendo absorto las conversaciones de los mayores. Ellos serían los encargados de moldear la personalidad de un adolescente que a los trece años ya había perdido a su padre. Paseaban por las calles de la ciudad, acudían al Orfeón fundado por A. Rico y por el Maestro Poveda ${ }^{5}$, asistían a veladas musicales y teatrales, pero sobre todo hablaban y hablaban de todo lo imaginable, de Dios, del Universo, de Dicenta, de Galdós - los estrenos de Juan José y Electra fueron auténticos acontecimientos sociales en Alicante ${ }^{6}$ - , de Renán, de la miseria, la explotación, del caciquismo o de la igualdad entre los hombres. Otros jó-

3 Para el republicanismo alicantino de finales del xIX, véase: GutIÉRREZ LLORET, R.A., El republicanismo en Alicante durante la Restauración. Ayuntamiento de Alicante. Alicante, 1989.

4 ESPLÁ Rizo, C., El Luchador, 4 de febrero de 1926. Alicante.

5 El Orfeón fundado por el Dr. Rico no era solamente una asociación musical, sino una especie de fundación, sufragada totalmente por Antonio Rico, en la que las clases más necesitadas de la ciudad aprendían música, canto, literatura, filosofía, iniciándose, también, en los ideales republicanos. El Dr. Rico, uno de los médicos más prestigiosos de Alicante, invirtió en él buena parte de su fortuna personal, ya que no sólo ayudaba a sus discípulos espiritualmente.

5 Moreno Sáez, F., El movimiento obrero en Elche, 1890-31. Instituto de Cultura Juan Gil-Albert, Alicante, 1987. Dice Moreno Sáez que durante muchos años el acto principal del Primero de mayo en Elche fue la representación de Juan José. Respecto a Electra, Galdós asistió a la representación en el Teatro Principal de Alicante, siendo conducido a hombros de los asistentes hasta la estación de ferrocarril entre vítores y aclamaciones de la multitud. 
venes se fueron sumando al grupo -Alonso Mallol, A. Pascual, los hermanos Botella, L. Carbonell, Pascual Ors y A. Farga-, la mayoría procedentes de la Escuela Modelo que dirigía la familia Albricias ${ }^{7}$. Entre todos fundarían el diario El Luchador, auténtica escuela de republicanismo combativo inspirada por el magisterio de Antonio Rico y Salvador Sellés. En sus páginas publicaría Esplá multitud de escritos denunciando las arbitrariedades, corrupciones y abusos del régimen. Uno de ellos, escrito en 1916 y dirigido a Francos Rodríguez, le costaría el destierro por cuatro años a Valencia, ciudad en la que conocería a Roberto Castrovido, Marcelino Domingo, los hermanos Just, los hermanos Estellés, Blasco Ibáñez y Felix de Azzati, integrándose plenamente en los ambientes republicanos que impregnaban la redacción de El Pueblo y la Casa de la Democracia.

Unos meses antes de la dictadura de Primo de Rivera, en marzo de 1923, Esplá marcharía a París como corresponsal de varios periódicos valencianos, obteniendo al poco tiempo las de El Liberal, El Heraldo, El Sol, La Voz, de Madrid, y La Vanguardia, de Barcelona. Unamuno, Blasco lbáñez y Amadeo Hurtado, con quienes colaboró en multitud de ocasiones, serían en esta ocasión sus maestros. Con ellos se convirtió en el auténtico motor de las luchas contra la dictadura española en París. Después vendría la República, Azaña, los cargos públicos, el contraste entre el deseo y la realidad, los cristales rotos de la guerra, la amargura larga y oscura de exilio.

Carlos Esplá se educó en un ambiente muy propicio al republicanismo, educación que se iría conformando al calor de los acontecimientos que sacudieron España y Europa durante las dos primeras décadas del siglo, desde el caso Dreyfus, a la Semana Trágica, pasando por la revolución rusa, la huelga del 17, la guerra de Marruecos o la guerra mundial. A ello hay que añadir la huella tremenda que en él dejaron sus sucesivos maestros: Antonio Rico, Salvador Sellés, Roberto Castrovido, Blasco Ibáñez, Miguel de Unamuno, Amadeo Hurtado y Azaña, sin olvidar la enorme influencia que para los jóvenes de su generación —una generación dinámica, abierta, demócrata y culta dispuesta a abandonar el pesimismo y la inercia de generaciones anteriores-, ejercieron las iniciativas de Ortega, especialmente la Liga para la Educación Política, la revista España y el diario El Sol, ni las campañas antiflamenquistas de Eugenio Noel o los manifiestos de la Liga Antigermanófila.

7 Para esta cuestión, véase: Apafici Diaz, A., La Escuela Modelo de Alicante. Alicante, 1997. 


\section{EL ANTICLERICALISMO EN EL PENSAMIENTO DE CARLOS ESPLÁ}

El joven Esplá participaba de lo que tradicionalmente había sido una constante del republicanismo español: el anticlericalismo. Aunque conviene aclarar que la actitud republicana ante el hecho religioso no fue nunca homogénea, como tampoco lo fue la de los anticlericales. La Parra y Suárez Cortina afirman que los anticlericales de principios del siglo XIX no ponían en duda el dogma católico, sino que pretendían la reforma de la iglesia y de la religiosidad. Es a partir de 1868 cuando el anticlericalismo adquiere unas connotaciones agnósticas o ateas y aspira a la reducción del papel de la Iglesia en la sociedad, para, progresivamente, hacerla desaparecer ${ }^{8}$. Pero el anticlericalismo no era sólo un problema de creencias, sino que «expresaba todo un complejo de relaciones en modo alguno reducible a sus aspectos políticos, jurídicos, sociales o ideológicos ${ }^{9}$. En la llamada cuestión religiosa se habían centralizado toda una serie de confrontaciones, ideológicas, sociales, institucionales, incluso económicas, entre dos modelos opuestos de ver el mundo ${ }^{10}$ : a un lado la sociedad tradicional con sus estructuras ancladas en el antiguo régimen y el sometimiento del hombre a lo sobrenatural, a lo inexplicable, a la ley divina; a otro, los herederos de la llustración, de la Revolución Francesa, del racionalismo que aspiran a organizar la sociedad a la medida del hombre, a explicar el mundo de acuerdo "con argumentos inmanentes, sin cifrar en lo divino o trascendente la última motivación» ${ }^{11}$.

El enfrentamiento de los republicanos españoles con la Iglesia Católica, aminorado cuantitativamente tras el triunfo de la monarquía, se vería impulsado en el último tercio del siglo pasado por varias razones: una el artículo 11 de la Constitución del 76 que reconocía la confesionalidad del Estado y que, aunque recogía la libertad de conciencia, suponía un espaldarazo muy notable al papel preponderante de la Iglesia Católica en España; otras, la encíclica Quanta Cura de 8 de noviembre de 1864, el Syllabus Errorum y el Concilio Vaticano I, que establecían la incompatibilidad entre el catolicismo y el liberalismo ${ }^{12}$, cerrando así cualquier tipo de apro-

\footnotetext{
8 La ParRa, E y SuÁrez Cortina, M., El anticlericalismo español contemporáneo. Biblioteca Nueva, Madrid, 1998, pág. 13.

9 SuÁREZ CORTINA, M., "Anticlericalismo, religión y política durante la Restauración», en LA. Parra, E. y SuÁrez Cortina, M., El anticlericalismo español..., pág. 130.

10 Ibídem, pág. 130.

11 Ibídem, pág. 13.

i2 Marichal, J., El secreto de España. Taurus. Madrid, 1995, págs. 136-137.
} 
ximación entre ambas posturas. Estos hechos provocaron que la cuestión religiosa, que desde siempre había ocupado una parte del programa republicano, ahora pasase a convertirse en tema nodal. Se alcanzaba así el punto culminante en la quiebra de unas relaciones que nunca habían sido buenas. La transacción entre Iglesia y modernidad, entre iglesia y liberalismo se había hecho inviable, anulando los intentos de una parte del krausismo por conseguir un catolicismo liberal, cuestión por la que habían luchado con denuedo hombres como Gumersindo de Azcárate o Fernando de Castro ${ }^{13}$. Para los republicanos la libertad de conciencia era tema indiscutible, para la Iglesia era un atentado contra su poder y dignidad. En España, los republicanos culpaban a la Iglesia-institución de ser aliada indispensable de la plutocracia en el poder y por ello causante directa de la situación por la que atravesaba el país. Además, al igual que muchos intelectuales de la generación del catorce, Ortega, Pérez de Ayala, Carande, Azaña, educados en instituciones religiosas, los republicanos creían que la Iglesia había llenado notablemente un periodo de la historia de España con los Soto, Vitoria, Suárez, Mariana, Luis de León, Juan de Avila, pero que a principios del siglo $x x$ se había transformado en un organismo inmovilista, en una rémora para el desarrollo nacional aliada a las capas más intransigentes de la sociedad.

Tras la encíclica Inmortali Dei de 1895, que afirmaba la compatibilidad de la Iglesia con cualquier tipo de régimen, se produce una ruptura en el republicanismo español ante la cuestión religiosa. Los grupos de Castelar y de Ruiz Zorrilla aproximaran su pensamiento político a posturas muy

13 SuÁrez Cortina, M., Anticlericalismo, religión y política en la Restauración, en La ParRA López, E. y SuÁrez Cortina, M., El anticlericalismo..., pág. 134. A este respecto dice Suárez Cortina: «Situando en el centro de sus planteamientos la reforma ética del hombre, el krausismo se presentaba como una filosofía profundamente religiosa... El contraste entre sus principios religiosos y los dogmas de la Iglesia católica situaron a los krausistas en una posición extremadamente delicada que acentuó los caracteres de sus crisis propiciando algunas de las manifestaciones más firmes de religiosidad a mediados del siglo pasado: la Memoria Testamentaria (1874) de Fernado de Castro, la Minuta de un Testamento (1876) de Gumersindo de Azcárate y la Iglesia Española (1876) de Francisco Giner de los Ríos. Estos autores situaron el problema religioso en la falta de sintonía del catolicismo como religión positiva en relación a las transformaciones sociales y científicas del mundo contemporáneo y conformaron la cristalización de un reducido, pero influyente, núcleo de intelectuales que, a su pesar, tuvieron que alejarse de la iglesia católica". Por su parte Elía Díaz asevera: cLa filosofía krausista es explicitamente una filosófía no sólo abierta a la religión, sino también, en cierto modo, fundamentada en ella... Pero dadas sus discrepancias con respecto del catolicismo integrista, en especial con respecto del mayoritariamente intransigente catolicismo español de la época.... no es de extrañar que ésta fuese en seguida calificada entre nosotros de filosfía absolutamente perniciosa y rechazable, a pesar de su carácter sincera y abiertamente religioso". DíAz, E., Filosofía social del krausismo español. Fernado Torres, editor. Valencia, 1983 , pág. 53. 
cercanas a las defendidas por los católicos ${ }^{14}$. Castelar creía que si la lglesia se había opuesto a la democracia tradicionalmente no era por razones profundas, sino porque durante siglos el gobierno católico había estado bajo el control de los jesuitas. El oscurantismo, el fanatismo, la intolerancia partían de ese dominio. Para Castelar, a partir de 1895 se produce una inflexión al quedar libre la Iglesia de esa tiranía gracias a la citada encíclica, que abría las puertas a un periodo relativamente armónico entre la Iglesia y los regímenes no confesionales. Castelar responsabilizaba a los jesuitas de la historia negativa del catolicismo y veía en la estrategia seguida por León XIII un cambio de singladura que haría posible la convivencia entre democracia y religión; en este sentido será considerado como un antecedente directo de la Democracia-Cristiana ${ }^{15}$. En el cambio de actitud de este sector del republicanismo, pesaría mucho el ralliement de León XIII ante los acontecimientos sucedidos en Francia, donde los gobiernos radicales habían iniciado una serie de reformas del sistema educativo que dejaban a la iglesia completamente fuera del mismo.

Por otra parte, los federalistas y el resto de grupos republicanos continuaron en su línea tradicional. Habían bebido en «filosofías sociopolíticas tan distintas como el positivismo, el krausismo o el hegelismo", pero también en el cristianismo primitivo, «la moral cristiana se mostraba acorde con los principios racionales del hombre libre» pero siempre que se mantuviese independiente del Estado ${ }^{16}$. El problema no radicaba en la bondad o maldad de la doctrina, sino en el mal uso que se había hecho de ella hasta pervertirla y pasar a ser uno de los principales obstáculos al progreso de la humanidad.

Carlos Esplá, mucho más próximo a las posiciones federalistas que a las de Castelar, se declaró ateo y libre de Dios en numerosísimas ocasiones. Para él no se trataba de dilucidar las calidades del cristianismo. Era una cuestión estrictamente positivista. La Iglesia de Cristo, la doctrina cristiana podía haber sido un compendio de bondades en su origen, pero a principios del siglo $x x$ esa doctrina se había corporeizado en una institución cuyas líneas de pensamiento eran completamente contradictorias con el bienestar y la libertad del ser humano, es decir, la doctrina inicial iba por un lado y la praxis por su opuesto, por tanto se trataba de una institución, de un credo falseado que tenía unos fines contrarios a su predicamento.

14 Andrés-Gallego, J., «La última evolución política de Castelar». Hispania, n. ${ }^{\circ} 115$. Madrid, 1970, págs. $385-393$.

15 Suárez Cortina, M., Anticlericalismo..., págs. 60-70.

16 Ibídem, pág. 71. 
Pero es que, aunque existiese esa adecuación entre teoría y práctica, en iguales circunstancias históricas también la habría combatido, ya que el problema principal para Esplá estribaba en la total separación de la Iglesia y del Estado, en el retroceso de la Iglesia al ámbito que nunca debió abandonar: el de la intimidad de la conciencia personal. La Iglesia y la religión en tanto en cuanto subsistieran como elementos alienadores del ser humano en particular y de la sociedad en general, y mientras tuviesen poder sobre las conciencias y sobre los bienes, deberían ser combatidas hasta su desaparición.

Esplá fue un anticlerical convencido, incluso antirreligioso. Pensaba que había que luchar con todos los medios posibles contra la Iglesia Católica, incluso atacando la doctrina católica porque esta tenía poco que ver con la originaria. Antes al contrario era fruto y argumento de la superestructura eclesiástica organizada; pero, ante todo, la religión cercenaba la libertad del hombre. Ni la doctrina, ni la práctica podían quedar a salvo puesto que ambas eran las caras de una misma moneda puesta al servicio del régimen y la oligarquía. La Iglesia había hecho en un tiempo grande a España, ahora la empequeñecía, no quedaba otro remedio que destruir ese obstáculo y para ello cada uno debía utilizar los instrumentos que le fuesen más propicios, en su caso la pluma iba a ser el arma elegida. Escribiría cientos de artículos tratando la cuestión religiosa, muchos de ellos, especialmente los de la primera época, en un tono furibundo como forma de llamar la atención sobre el problema: «Salimos de este año leproso y repugnante como si nos hubiésemos librado del tifus... Hay que festejar su muerte con doce marsellesas, doce golpes de hoz, doce blasfemias... y al comer las uvas hemos elevado doce oraciones heroicas: para que se salve la libertad, para que se salve Rusia, para que se derrumben todos los templos y se abran todas las cárceles y se cierren todos los cuarteles. Para que se borre de todas las conciencias la idea de Dios, para que desaparezcan todos los reyes... para que presenciemos el exterminio del clero, para que no haya tisis» ${ }^{17}$. La cárcel, el cuartel y la iglesia son para él los tres basamentos del poder reaccionario, todos ellos envueltos y protegidos por el temor que la idea de Dios proporciona a los hombres. Al igual que muchos federales, piensa que monarquía, iglesia y reacción son una misma cosa. La idea de Dios tal como ha sido defendida y difundida

17 Esplá Rizo, C., «Las doce uvas de esta Noche Vieja». El Pueblo, enero de 1922. APCE. Alicante. En este escrito es palpable la influencia en Esplá de los escritos del político catalán Sunyer i Capdevila. Para la vida de Sunyer se puede consultar el siguiente libro: SÁnCHEz MARTiNEZ, G., Guerra a Dios, a la tisis y a los reyes: Francisco Suñer y Capdevila, una propuesta materialista para la II mitad del siglo XIX español. Ediciones UAM. Madrid, 1987. 
por la iglesia no es sino una idea de miedo que impide a los hombres su propia realización, que limita el desarrollo de su personalidad, en fin, que reprime lo más grande que éste tiene: su libertad. El periodista alicantino se identifica con el pensamiento de Pi y Margall: ni la revelación, ni las supersticiones podían "subordinar la absoluta libertad de pensamiento establecida sobre la autonomía de la razón. Ni la autoridad del Estado, ni la de la Iglesia, ni aquella que se basaba en tradiciones de siglos podían someter la razón individual» ${ }^{18}$. Equipara la presencia de Dios en las conciencias de los hombres con la tisis, la lepra o el tifus, con la muerte del individuo, de la razón, con una plaga contra la que había que vacunarse si se amaba la vida, si se quería que el hombre llegase a la plenitud.

La religión partía de la fe como principio básico que escapaba al ámbito de la razón, pero todavía había algo peor que esto: la fe ciega que se había encaramado a la conciencia de muchos españoles a lo largo de muchos años de iniquidad, lo que equivalía a la completa degradación del espíritu humano ${ }^{19}$. De ahí que uno de los ejes de las críticas de Esplá a la Iglesia, por tanto a la religión, sea el papel que esta desempeña en la enseñanza.

En la Europa del cambio de siglo, sobre todo en Francia, se había planteado seriamente "el problema de la libertad de enseñanza y el de las funciones docentes del Estado» ${ }^{20}$. Este debate se estaba siguiendo muy de cerca por la opinión pública española, que desde 1880 venía observando una ofensiva de la Iglesia en ése y otros campos ${ }^{21}$, como los demuestran la fundación de los colegios jesuitas de Málaga, en el que estudiarían Pérez de Ayala y Ortega ${ }^{22}$, Sarriá, Chamartín o el del Puerto de

18 Suárez Cortina, M., Anticlericalismo, religión y política en la Restauración. En La ParRa, E y SuÁREZ CoRTINA, M., El anticlericalismo en..., pág. 150.

19 Díaz, E., La filosofía social del..., pág. 55. Sanz del Río, citado en esta obra por Elias Díaz. Dice SANz DEL Río: "La fe, como la religión, dessansa en principios y en razón, y a ésta debe conformarse... La fe ciega, sin regla y sin motivos, es una regegación del pensamiento y de la libertad; esto es, la degradación del espíritu humano».

20 MARICHAL, J., «El secreto....», pág. 136.

21 SuÁREz CORTINA, M., Anticlericalismo, religión..., pág. 154-155. Dice Suárez Cortina que: «la iglesia desde los 90 dió paso a una nueva generación que hizo de las prácticas religiosas y de las movilizaciones populares un modo de afirmación religiosa. Una especie de reacción eclesiástica al proceso de secularización... Se fomentaron las devociones marianas, se organizaron misiones, estableciendo diversos modos de participación: jubileos, cofradías, ligas católicas, peregrinaciones, todo un modo de participación, de integración religiosa que constituía, al fin, una forma de sociabilidad. Fue, precisamente, en este medio, cuando en el clima de la crisis se produjo la oleada de frailes, tras la pérdida de las colonias y la política anticlerical francesa.

22 La estancia de Pérez de Ayala en el colegio jesuita de «El Palo de Miraflores» de Málaga sirvió de inspiración para su novela más conocida "AMDG". 
Santa María, y las universidades de Deusto, jesuita, y El Escorial, agustina ${ }^{23}$. Esta ofensiva se acrecentará conforme las reformas de la Tercera Republica francesa avancen. El ascenso de la iglesia en el control de la enseñanza llegó hasta tal punto que en 1901 Romanones, a la sazón ministro de Instrucción Pública, se vio obligado a preparar una andanada de proyectos legislativos para frenar su expansión, dentro de lo que sería una constante del liberalismo dinástico hasta la muerte de Canalejas en 1912.

También en esta década, fruto de la ofensiva eclesiástica y de la situación por la que atravesaba el país, resurge, vigoroso, el anticlericalismo en su doble vertiente: social y doctrinal, alcanzando su punto álgido en la Semana Trágica de Barcelona. La Iglesia se opuso frontalmente a las reformas de Romanones y la polémica subió de tono, llegando a intervenir en el debate abierto hasta Miguel de Unamuno con un discurso pronunciado el 24 de abril de 1902 en Valencia, en el afirmaba que quienes hablaban más de libertad de enseñanza «eran los enemigos de la actual cultura europea» ${ }^{24}$. Para Unamuno, en el caso español, sólo el Estado podía garantizar la libertad: Estado y liberalismo eran sinónimos. La libertad de enseñanza que defendían los católicos no era sino un retroceso en la historia. Ortega terció también en la polémica defendiendo una posición absolutamente idéntica a la del catedrático de Salamanca. La discusión se prolongaría décadas hasta terminar, dramáticamente, en la guerra civil de 1936. En ella participó Esplá con vehemencia. Para él la Iglesia perseveraba en el control de la enseñanza porque ese era el instrumento principal para mantener bajo su dominio a la población. Su preponderancia educativa garantizaba el mantenimiento del orden establecido, en el cual la lglesia ocupaba un lugar privilegiado, por tanto era menester desalojarla de los centros de enseñanza o el país no saldría nunca del oscurantismo. El modelo a seguir no podía ser otro que el de la Tercera República francesa: "Combes era un bravo adversario de Dios y de sus sacerdotes. Partió con un hachazo de ideal el Concordato napoleónico y divorció a Francia del catolicismo. Cada palabra de Combes encendía en Francia una guerra de ideales y apagaba un cirio. Prohibió a las órdenes religiosas el derecho a dedicarse a la enseñanza embrutecedora e incivil y los persiguió a latigazos. Francia fue laica, bella y grande por la obra de este viejecito de Pons. De esa Francia nos enamoramos los jóvenes.... ${ }^{25}$. Francia había conseguido que el Estado liberal monopolizase la enseñanza. Después de duras

23 MARICHAL, J., El Secreto de..., pág. 136.

24 MaRichaL, J., lbídem, pág. 139.

25 Esplá Rizo, C., «Emilio Combes». El Pueblo, 1922. APCE. Prensa. Alicante. 
y enconadas batallas la escuela laica y única para todos se había impuesto al otro lado de los Pirineos, siendo el primer país europeo en el que la Iglesia había sido totalmente apartada del sistema educativo. Por ello - argumentaba Esplá - los jóvenes franceses serían educados en libertad, sin condicionamientos, sin miedos, y la Francia del futuro sería un país cada día más libre y más justo. Su influencia sobre los republicanos españoles sería tremenda. Esplá opinaba que mientras la Iglesia siguiese dominando la educación de los españoles, éstos continuarían sumidos en la apatía, persistiría el privilegio de las clases pudientes - perpetuándose en el poder por tiempo indefinido-, y permanecería el miedo atenazando las potencialidades infinitas del pueblo. Religión e Iglesia eran una misma cosa y ambas tenían en el miedo, inoculado en las venas del pueblo a través de sus centros educativos, su principal instrumento de poder. Había que combatir a la religión católica en todos sus ámbitos, pero también era preciso comenzar a actuar positivamente para crear un hombre nuevo libre de temores: «...En Valencia muchos centenares de niños llenan las aulas de las escuelas laicas, en una gloriosa liberación de la brutalidad religiosa. ¡Niños que son buenos sin el cruel y perverso temor del infierno!. Esas escuelas son la obra viva y eterna del republicanismo valenciano... Son los hombres laicos del mañana que han de arrancar de las conciencias la idea de Dios; son la futura generación republicana, llena de rebeldías y de ansias de libertad. Cuando en las noches invernales veo los automóviles enormes, lujosos, iluminados de los jesuitas, de los maristas, cargados de niños ricos, recuerdo nuestras pobres escuelas laicas desde donde germina una juventud libre $y$ atea» ${ }^{26}$.

El dominio clerical de la enseñanza tenía para Esplá dos funciones principales: una crear una elite dirigente que perpetuase en el poder a las clases que lo habían detentado secularmente y con las que tan buenas relaciones había mantenido la Iglesia; otra, amordazar y atemorizar al pueblo. En ese contexto, la enseñanza laica del Estado sería la llave de la liberación y la emancipación del pueblo, ya que pondría en sus manos los instrumentos necesarios para ello: la razón, la cultura, la libertad y la justicia.

Sin embargo, Valencia era una isla republicana en un mar monárquico en el que la Iglesia encontraba su ambiente más propicio. La ofensiva desencadenada por el catolicismo tras la Restauración había puesto una de sus metas en la educación. La llegada de religiosos franceses y otros pro-

26 ESPLÁ RIzo, C. «Un templo sin Dios». El Pueblo, 1922. APCE. Prensa. Alicante. 
cedentes de las antiguas colonias españolas habian reforzado ampliamente esta tendencia ${ }^{27}$, hasta tal punto que en ciudades de un anticlericalismo tradicional como Alicante, la implantación de colegios católicos estaba teniendo un éxito insospechado, lo que hacía a Esplá enfatizar más aún sus ataques: «Alicante se llena de curas, de frailes, de jesuitas y sacristanes. Esto es mucho peor que llenarse de piojos. Esto es perder la esperanza de estar limpios, de que sean honestas las mujeres y de que se pueda comer» ${ }^{28}$. Conforme en Francia se asentaban más las reformas educativas, en España aumentaban los colegios religiosos. En Alicante, a juicio de Esplá, había crecido mucho la presencia de religiosos católicos poniendo en riesgo el espíritu liberal de una ciudad en la que en su juventud «el pueblo apedreaba a los jesuitas... disolvía a estacazos las procesiones y era muy difícil que un cura pasease tranquilamente por la calle» ${ }^{29}$, y lo peor de todo es que esto ocurría desde que Alicante estaba gobernado por los liberales de Canalejas: «el pueblo que antes apedreaba a los jesuitas, hoy les da un magnífico terreno para edificar su residencia... Mientras ese pueblo deja morir, desaparecer, la Asociación Alicantina de la Caridad, los salesianos construyen un magnífico edificio con sus puertas blindadas. Mientras desaparecen las escuelas laicas, la gente bien pone de moda la necia pedagogía de los hermanos maristas... Porque los liberales alicantinos son liberales de credo y escapulario, de adoración nocturna y de cofradía...» ${ }^{30}$.

Por otra parte, a la hora de analizar el anticlericalismo de Esplá es preciso tener en consideración el contexto histórico en el que se desenvolvía. Al tradicional anticlericalismo de buena parte de los republicanos hay que añadir, como elemento radicalizador, esta ofensiva de las ordenes religiosas por el control de la enseñanza. Como afirman La Parra y Cortina «el anticlericalismo se desarrolla más allí donde se registra una situación de dominio clerical y alcanza mayor virulencia cuando este dominio es más acusado" ${ }^{31}$.

Sin embargo, el anticlericalismo, la antirreligiosidad de Esplá podría analizarse desde otra perspectiva que matizaría un poco lo afirmado hasta ahora. Evidentemente estamos ante un anticlerical en el sentido

27 La Parka, E. y SuÁREz CORTINa, M., El Anticlericalismo..., págs. 154, 155.

28 EsPlÁ Rizo, C., «A los republicanos de Valencia. Vuestra hermana Alicante». El Pueblo, 23 de agosto de 1916. Valencia.

29 ESPLÁ RIZO, C., "A los republicanos de Valencia....".

30 ESPLÁ RIzo, C. «A los republicanos de Valencia...». El Pueblo, 23 de agosto de 1916. Valencia.

31 La Parra, E. y SuÁrez Cortina, M., El anticlericalismo..., pág. 13. 
más amplio y radical del término. Anticlerical por educación: tanto su familia paterna como materna habían sido tradicionalmente republicanas y sentían más adoración por Garibaldi o Victor Hugo que por cualquier eminencia eclesiástica; su abuelo Rafael Rizo era un masón profundo; el Dr. Rico, un ateo sin fisuras, y Salvador Sellés, un librepensador. Por tanto es seguro que sus oídos infantiles oirían más veces el nombre de los revolucionarios franceses o italianos que los salmos del párroco de la iglesia de Benalúa. Pero, además, era anticlerical por sentimiento y por convicción intelectual. Estamos también ante un ateo circunstancial, o como él mismo dice en ocasiones «un hombre sin Dios». Sin embargo, no se puede olvidar, como se ha dicho anteriormente, que uno de sus mentores fue Salvador Sellés, poeta eminentemente laico, pero de un espíritu profundamente religioso, de una religiosidad pura, primitiva, bebida directamente de las fuentes del cristianismo primigenio y cuya máxima vital era «no basta con no hacer el mal, es preciso hacer el bien», pensamiento muy en la línea de lo expuesto por Pi y Margall ${ }^{32}$. Se trataría de un cristianismo militante, activo, apartado de toda liturgia. El cristianismo de Sellés era una actitud ante la vida que le empujaba a denunciar lo injusto, a luchar por mejorar las condiciones de vida de aquellos que sufren, pero a mejorarlas aquí, en la tierra. Era también un comportamiento ético que se incardinaba perfectamente en su republicanismo. Como dice Suárez Cortina, el republicanismo tenía también un fuerte componente cristiano que «más allá de dogmas determinados alimentó y estimuló sus concepciones del hombre" ${ }^{33}$. En esa misma línea de pensamiento se expresaba el Unamuno de principios de siglo cuando decía que «el liberalismo es ante todo una teología y como tal no trata solamente de realizar reformas sociales y económicas, sino que ha de tender al desarrollo de la conciencia de los españoles para que todos fuesen libres espiritualmente" ${ }^{34}$. Teniendo en cuenta lo expuesto se podría llegar a afirmar, con todas las precauciones que se quieran, que los escritos y la ideología de Esplá tenían algo de religioso, formal y conceptualmente, pero religioso en el sentido que le daban Unamuno o Sellés, éste último encendido enemigo del dogmatismo de todas las religiones y un cristiano sin iglesia como demuestran sus odas A Dios, A la Providencia o Al infinito. Al igual que Sellés, Esplá creía en la bondad del hombre y admiraba profundamente cualquier sentimiento que saliera del corazón del pueblo, incluso si éste era contrario a sus convicciones como ocurría con muchas expresiones

32 SuÁREZ CoRTINA, M., «Anticlericalismo...», pág. 62.

33 La Parra, E. y SuÁrez Cortina, M., El anticlericalismo..., pág. 150.

34 Marichal, J., El secreto de..., pág. 101. 
de religiosidad individual, expresiones que podían ser achacadas a la incultura o a la manipulación, pero nunca a la mala fe del pueblo que derrochaba en ellas todo su sentimiento: « Protege a mi hijo!, ¡Líbralo de la maldad del mundo! Aquel niño cuya protección se pedía al Dios de la Colegiata era Sellés. Yo he salvado mi espíritu de ese Dios y mi cuerpo de esa iglesia. Pero ante esa página emocionante, ¿Como no ver en aquella madre, nuestra propia madre, poniendo en sus rezos el más dulce cariño humano?» ${ }^{35}$. Patente es, también, su admiración por la religiosidad de Gabriel Miró: "Nómada fue la lectura que marcó en mi vida el adiós a la infancia. Me sentía atraído por la gravedad, la sencillez, la bondad que como un perfume se desprendía de la prosa de Miró. Mi admiración por él fue silenciosa y recatada. Yo sentía honda emoción cuando lo veía, y unos impulsos incontenibles de besarle la mano. Miró, con su santidad de hombre, me daba una sensación de pura religiosidad, fuera de todas las religiones. Muchas veces fui vecino suyo en Benalúa, veía abierto e iluminado el balcón de su casa..., permanecía algunos momentos bajo aquel balcón como un devoto ante el altar...» ${ }^{36}$. En Esplá había un enorme respeto por todo sentimiento que fuese auténtico, más todavía si éste tenía origen popular y el sentimiento religioso del pueblo tenía para él mucho de sincero, de sentido. Otra cosa bien distinta era que él no fuese creyente y que opinase, también muy sentida y racionalmente, que la Iglesia Católica en España era una institución reaccionaria al servicio de los sectores más caducos de la sociedad, que fuese imprescindible quitarle el enorme poder que detentaba hasta reducirla a lo que debiera haber sido su único ámbito: el interior de los templos, o que pensase que la religión había sido secularmente un instrumento de dominio del hombre por el hombre.

Para Esplá, formalmente, el compromiso político tiene algo de religioso. El buen republicano precisa tener fe, ha de confiar en el futuro y someterse a una disciplina, pero sobre todo ha de ser consciente de que su individualidad estará siempre supeditada al objeto de su militancia: la República y algo consustancial a ella: el progreso del hombre. Ni los intereses económicos, ni los personales, ni los familiares pueden condicionar o modificar su compromiso. En este sentido, emplea abundantemente términos extraídos del vocabulario religioso para describir un sentimiento o para ensalzar a una persona querida, para definir lo que para él era un buen republicano o para hablar de un comportamiento recto. Es muy frecuente

35 Espla Rizo, G., Recortes de prensa. El Luchador. APGE. Prensa.

36 Esplá Rizo, C., El Luchador, 28 de mayo de 1930. Artículo homenaje a Gabriel Miró. 
encontrar en sus textos palabras como estas: calvario, reliquia, escapulario, santidad, peregrinaje, Cirineo, apóstol, religiosidad, pasión, penitencia, términos que también estaban muy presentes en el vocabulario de muchos escritores republicanos del tiempo y que sugieren, tal vez, cierta idealización del cristianismo original.

En fin, se puede afirmar, resumiendo lo dicho, que es en el ámbito de la moral individual donde la religión queda al margen de sus ataques. Fuera de ese espacio toda energía será insuficiente para combatir la idea de Dios, la religión o el clero, porque para él, como para tantos republicanos, ese combate tenía por finalidad la modernización de España y la plena realización humana de sus ciudadanos. La lucha contra el predominio eclesiástico la entiende como lucha inevitable para el progreso del país y de las conciencias ${ }^{37}$. Aplicando a Esplá lo afirmado por La Parra y Suárez Cortina se podría decir que "su anticlericalismo no es sólo el rechazo del poder clerical, sino también un intento de dotar al hombre de capacidad, por sí mismo, para explicarse y para organizar la sociedad» 38 .

\section{ESPLÁ Y LA MASONERÍA. EXPLICACIÓN DE UN VÍNCULO}

Según Gómez Molleda la trayectoria de la masonería a lo largo del presente siglo es paralela al discurrir histórico de España ${ }^{39}$. Así, cuando a partir de 1917 el país se convulsiona y se dispone a dejar constancia de su descontento, de su oposición al régimen y de sus ansias de renovación, el Grande Oriente Español emprende una serie de reformas internas para transformarse en un instrumento útil para la lucha contra la opresión ${ }^{40}$. Hasta entonces la masonería se había movido dentro de un discreto apoliticismo, predominando las corrientes filosóficas y abstencionistas defendidas, entre otros, por Augusto Barcia y Demófilo de Buen. A partir de 1917, pero sobre todo después de la Asamblea extraordinaria de 1926, se producirá un cambio sustancial que terminará con el triunfo de las tesis intervencionistas ${ }^{41}$. J.S. Vidarte dice que cuando entró en la masonería en 1923 encontró en su seno dos tipos de personas: los que se habían hecho

\footnotetext{
37 La Parra López, E. y SuÁrez Cortina, M., El anticlericalismo..., pág. 13.

38 Ibídem, pág. 13.

39 Gómez Molleda, M.D., La masonería en la crisis española del siglo $x x$. Taurus. Madrid, 1986, pág. 7.

40 bídem.

41 Avilés FarRe, J. La izquierda burguesa en la Segunda República. Espasa. Madrid, 1985, pág. 42.
} 
masones por cuestiones filosóficas o espirituales, y aquellos que ingresaron por razones estrictamente políticas ${ }^{42}$.

La masonería se surtía fundamentalmente de un sector de las clases medias mesocráticas urbanas incómodas no sólo con la situación política del país, sino también con el comportamiento y el peso de la lglesia Católica en España. Muchos encontraron en las logias una forma nueva de encauzar sus inquietudes religiosas «frente al catolicismo oficial del Estado y las clases pudientes, la potenciación de las órdenes religiosas en el campo educativo y la imagen de riqueza y situación acomodada que daba el clero en Españas ${ }^{43}$. Pero, poco a poco serán más los que se acerquen a ella movidos por motivos eminentemente políticos, debido, entre otras cosas, a la tolerancia relativa de la dictadura ${ }^{44}$ : si bien la masonería estaba prohibida, se permitían sus reuniones y cuando, en algún momento, surgían problemas sus dirigentes los solventaban directamente con las autoridades. Así pues, la masonería servirá, en cierto modo, como sustituto de los partidos políticos, en ella se encuadrarán desde militantes decepcionados del Partido Reformista ${ }^{45}$ a miembros del Partido Socialista, pasando por republicanos independientes vinculados posteriormente a Acción Republicana.

Del grupo de Esplá, Álvaro Pascual Leone fue el primero en acercarse a la Orden en 1917, cuando se produjo la primera oleada de gente nueva en el GOE. Ese mismo año ingresaron personalidades tan significativas como Daniel Anguiano, Lucio Martínez Gil y Botella Asensi. En 1926 el GOE celebró una Asamblea extraordinaria en Alicante que fue decisiva para su futuro. En ella se aprobaron los estatutos y una nueva estructura interna basada en el federalismo y en una mayor autonomía de las logias regionales ${ }^{46}$, entre las que destacarian por su combatividad la Logia $R e$ gional de Levante, cuyos Grandes Comendadores fueron Marco Miranda y José Estruch ${ }^{47}$, y la Logia Danton de Madrid, de la que formaban parte Marcelino Domingo, José Salmerón y Antonio Lezama ${ }^{48}$. El GOE estaba

42 Vidarte, J.S. Todos fuimos culpables. México, 1973.

43 Gómez Molleda, M.D., La masonería en la..., pág. 115.

44 Ferrer BenimeLI, J.A., Masonería española contemporánea. Siglo XXI. Madrid, 1987. Vol. 2, pág. 59. Ferrer afirma que si bien el dictador no simpatizaba con la masonería, «algunos de sus subordinados extremaron la tolerancia con los masones. Por ejemplo, el general Barrera, que permitió la celebración en Barcelona de un congreso masónico prohibido por el dictador en Madrid".

45 lbídem, 124.

46 Ferrer Benimeti, J.A., Masonería española contemporánea. Desde 1868 hasta nuestros dias». S. XXI. Madrid, 1987. Tomo II, pág. 56.

47 Tanto J. Estruch como V. Marco Miranda fueron compañeros y amigos íntimos de Esplá.

48 AVILÉs FARRE, J., La izquierda burguesa..., págs. 42-108. 
dispuesto a hacer todo lo posible para atraer a su seno al liberalismo de izquierdas y convertirse en la principal plataforma de lucha contra Primo de Rivera. A esa estrategia responde la vinculación de la Orden a la Liga de los Derechos del Hombre, en la que militaban muchos intelectuales republicanos, y su aproximación a la revista España tras su reaparición en $1922{ }^{49}$. El mismo año de la asamblea alicantina, Martínez Barrio definió la masonería como «una sociedad de carácter universal, filantrópica y filosófica, cuyos postulados tienden a hacer reales y prácticas en la vida de los hombres los principios de igualdad, libertad y fraternidad" ${ }^{50}$. Las reformas y redefiniciones terminaron por calar en los sectores más liberales de la sociedad española y entre 1927 y 1928 se producirá una segunda oleada de afiliaciones tras el alta de Martí Jara y José Giral: «Ahora hemos entrado en la Masonería -escribe Martí Jara a Unamuno- para infiltrarle nuestra pasión política» ${ }^{51}$. A partir de este momento la implicación de las logias en los asuntos políticos del país será creciente, aunque siempre relativa: hay que tener en cuenta que pese a la calidad de sus miembros, su cantidad fue siempre pequeña: en 1925 tenía 2.750 afiliados ${ }^{52}$.

Aunque los objetivos de la masonería podían ser los que genéricamente había definido Martínez Barrio, la lucha contra la Iglesia Católica, y sobre todo en favor de la escuela laica, será su principal caballo de bataIla. Por otra parte, entre la masonería y el liberalismo progresista habrá simpre una interacción y una coincidencia programática, sería difícil evaluar si fue la masonería la que puso más énfasis en la cuestión religiosa o fueron los nuevos hermanos quienes llevaron a las logias por ese derrotero, cosa que tiene más posibilidades de ser cierta si tenemos en cuenta que dos de sus Grandes Maestres, Demófilo de Buen y Augusto Barcia, se opusieron rotundamente al intervencionismo político de la Orden.

Como bien señala Ferrer Benimeli, muchos de los que combatieron la Dictadura y posteriormente obtuvieron acta de diputado en las elecciones de junio de 1931, eran masones ${ }^{53}$. Lo era Esplá, y en grado alto, también sus amigos Just, Vargas, Miranda, Mallol, así como un extensísimo número de dirigentes republicanos, desde Lerroux a José Giral. Azaña acudió el 5 de marzo de 1932 a la logia madrileña de la calle del Príncipe para asistir a una tenida masónica, pero parece ser que los rituales iniciá-

Gomez Molleda, M.D. La masonería en la..., pág. 33.

lbídem.

28 de enero de 1928, carta de Martí Jara a M. de Unamuno. CMMU. Salamanca.

Gómez MolledA, M.D., La masonería en..., págs. 89-115.

Ferrer Benimeli, J.A., Masonería española contemporánea. Desde 1868 hasta nuestros dias. Siglo XXI, Madrid, 1987. 
ticos, las vestimentas y la parafernalia que allí observó le hicieron arrepentirse, por el momento al menos, de ingresar en la misma. La masonería de la época, lejos de ser un movimiento secreto, llegó a ser una moda entre ciertos sectores de la burguesía liberal e intelectual; sus reuniones se sabían por todos, sus talleres eran conocidos, 10 mismo que sus programas. No quiere decir esto que no hubiese algo de oscurantismo, de secretismo en sus reuniones, en la forma de comunicarse, pero si que no fue una secta cerrada cuyos miembros se reunían para idear planes, manejar gobiernos y perpetrar todo tipo de atentados y revoluciones ${ }^{54}$. Republicanos y masones coincidían en el modelo de enseñanza, el papel de la Iglesia, el sistema de libertades o los derechos del hombre, pero discrepaban en otras muchas cosas, incluso llegado el momento en que muchos de sus miembros ocupan puestos relevantes en la Administración, las logias se quejarán del poco caso que hacen de sus indicaciones ${ }^{55}$.

Los círculos masónicos habían venido desarrollándose en España, con nuevo impulso, desde principios de siglo, y aún más durante la dictadura. Ser masón era una forma más de combatir al régimen, de reunirse con gentes afines política e intelectualmente, lo que no impedía que desde ella algunos intentasen llevar a cabo sus planteamientos personales o convertir al GOE en un grupo de presión significado.

Carlos Esplá se hizo masón por dos razones esenciales. Primero por motivos familiares y ambientales: su abuelo Rafael Rizo fue masón convencido desde su juventud, al igual que sus maestros Rico y Sellés y muchos de sus amigos. La segunda razón es estrictamente política: Esplá no se introdujo en la masonería por motivaciones filosóficas o religiosas, sino por impulsos exclusivamente políticos; le parecía el instrumento, dadas las circunstancias históricas españolas, más eficaz para organizar la oposición al régimen, sobre todo si tenemos en cuenta que la Logia Regional de Levante, en la que militaba, era una de las más combativas y defensora a ultranza del intervencionismo político ${ }^{56}$. En Alicante, antes del destierro, Esplá mantuvo contactos con la logia Constante Alona, la más importante de la ciudad, pero no podemos afirmar si llegó a afiliarse. En Valencia sus relaciones con la masonería se intensificaron, ingresando en la logia Federación Levantina, integrada en la Logia Regional de Levante ${ }^{57}$, en 1922 con el nombre simbólico de Gorki; al año siguiente alcanzaría los

\footnotetext{
54 Ferrer Benimel., J.A., La masonería en la historia de España. Zaragoza, 1989, pág. 11.

55 Gómez Molleda, M.D., La masonería en la crisis..., pág. 15.

56 Ibídem, pág. 119.

57 Archivo Histórico Nacional. Salamanca. Sec. Guerra civil. Masonería, 141-3.
} 
grados segundo y tercero y poco tiempo después el grado Treinta y tres ${ }^{58}$. Comín Colomer afirma que Esplá fue durante muchos años el eje de la masonería en Levante y Sureste, especialmente en los años de la Dictadura ${ }^{59}$, cosa bastante extraña si se tiene en cuenta la relevancia masónica de personalidades como Marco Miranda o José Estruch y que Esplá residió en París entre 1923 y 1930. Bien es verdad que en la capital francesa fue uno de los masones más activos y que estuvo en contacto con sus hermanos valencianos para todas las acciones que emprendió contra la Dictadura, desde la introducción de los folletos de Blasco y los escritos de Unamuno hasta la conspiración de 1929, en la que sus mejores colaboradores, Pedro Vargas y Marco Miranda, eran destacados miembros de la Logia Regional de Levante ${ }^{60}$.

En París, Esplá ingresó en la logia Plus Ultra $452^{61}$, fundada en 1913 como sección española de la Gran Logia de Francia. Estaba situada en el número 16 de la calle Cadet $y$, al igual que la Liga de los Derechos del Hombre, era lugar muy concurrido por los exiliados españoles. La masonería estaba muy imbricada en las actividades políticas de los emigrados, pero no se debe sobrevalorar su importancia. La masonería francesa era muy fuerte en relación con la española, es posible que les ayudase económicamente en algún momento, que sirviese de intermediaria para poner en contacto a los exiliados entre sí y para introducirlos en los círculos políticos franceses, pero no fue la Orden la que instrumentalizó a los desterrados, sino al revés, fueron estos los que se sirvieron de sus medios para conseguir sus fines. Para introducir los folletos de Blasco o España con honra, Esplá se valió de sus amigos masones de Valencia, lo mismo que para los preparativos de la intentona revolucionaria de 1929. Utilizaron sus redes de comunicación, sus contactos, pero Esplá a quien recurrió fue a sus amigos, unos masones y otros no, el hecho de que fuesen masones podía darle un pequeño valor añadido, pero poco más. Si Vicente Marco Miranda y Pedro Vargas no hubieran sido masones, cosa difícil en aquel contexto, habría echado mano de ellos igualmente. Es decir, la intervención de la masonería en las conspiraciones contra la Dictadura fue un hecho real y notorio, entre otras cosas porque la mayoría de los conspiradores habían entrado en ella por motivos exclusivamente políticos, pero salvo en lo logístico, los hechos habrían ocurrido exactamente igual sin su intervención. En este sentido se expresaba N. Alcalá Zamora unos

\footnotetext{
Comin Colomer, E., Lo que España debe a la masonería. Madrid, 1952, pág. 164.

lbídem.

Gómez Molıeda, M.D., La masonería en la..., págs. 166-69.

Archivo Histórico Nacional. Salamanca. Sec. Guerra Civil. Masonería, 141-3.
} 
años después: «Para el triunfo de la República, que fue un movimiento espontáneo nacional, la masonería no ejerció influjo decisivo, ni necesario, ni apenas perceptible» ${ }^{62}$.

Durante la República Esplá perteneció a tres logias al mismo tiempo, la Federación Valentina, la Plus Utra de París, y otra madrileña cuyo nombre desconocemos. Sin embargo, Esplá podría enclavarse dentro del tipo de masones que al llegar al poder se olvidan bastante de las directrices marcadas por la Orden y actúan según su propio criterio político personal. Según el comisario Comín Colomer buena parte de los artículos más polémicos de la Constitución del 31 fueron aprobados en una reunión celebrada el 27 de junio de 1931 en la logia Plus Ultra de París ${ }^{63}$, a la que Esplá pertenecía; Vidarte afirma que él y la mayoría de los diputados masones recibieron cartas del GOE cuando se estaba debatiendo el artículo $26{ }^{64}$. Pero a pesar de esto y de las presiones que recibió desde Alicante ${ }^{65}$. Esplá, que había defendido una postura radical dentro de su partido respecto al citado artículo, terminó cediendo a los argumentos más moderados de Azaña, acordando una fórmula transaccional que incluía la disolución de la Compañía de Jesús. Ferrer Benimeli afirma que este punto se incluyó por la presión masónica ${ }^{66}$, pero es posible que tan sólo fuese una argucia política de Azaña para contentar a los más radicales e impedir que el artículo fuese aprobado tal como salió de la Comisión. Y es que, ser masón no era sinónimo de radicalidad anticlerical, dentro del Partido Socialista Indalecio Prieto, que no era masón, era uno de los más anticlericales, sin embargo, Fernando de los Ríos era mucho más moderado a pesar de su militancia masónica ${ }^{67}$. Igual ocurría en Acción Republicana, donde uno de los más recatados era Augusto Barcia.

62 Alcalá Zamora, N., Régimen político de convivencia en España. Buenos Aires, 1945, pág. 139.

63 COMin Colomer, E., La masonería en España. Madrid 1944.

64 VIDARTE, J.S., Las Cortes Constituyentes de 1931-33. Testimonio. Barcelona, 1978, pág. 199.

65 En pleno debate del artículo 24, luego 26, Esplá recibió un telegrama de la plana mayor de su partido en Alicante, firmado entre otros por José Estruch, en el que le conminaban a defender dicho artículo tal como había quedado en su primera redacción. Archivo Personal de Carlos Esplá. Alicante.

66 Ferrer Benimel, J.A., Masoneria española contemporánea. Desde 1868 a nuestros días. Vol. II. Siglo XXI. Editores. Madrid, 1987, págs. 90-91. Dice FerRer: «El que la disolución de los jesuitas fuera incluida en la Constitución ( art. 26), así como otros muchos puntos programaticos de las declaraciones masónicas más arriba comentadas, igualmente recogidos en la Constitución de 1931, es un hecho indiscutible. Lo que ya no se puede cuantificar ni valorar en su exacta media es cuáles ni hasta qué punto mucchas de estas cuestiones eran patrimonio de la forma de pensar de los masones, o simplemente formaban parte del ambiente político español del momento, cuya génesis, desarrollo e incluso virulencia difícilmente puede ser atribuido a una sola causa: la masonería".

67 Avilés Farre, J., La izquierda burguesa..., pág. 108. 
Porteriormente, Carlos Esplá continuó cumpliendo formalmente con sus hermanos, pero durante el tiempo que estuvo ligado a tareas de gobierno obedeció únicamente los dictados de su conciencia y de su partido, y ante la disyuntiva de seguir la disciplina del Partido o de su Logia, siempre seguiría la primera. Cuando acaba la guerra Esplá huye a París y vuelve a acercarse a las logias, que otra vez son el único recurso para la lucha, la solidaridad y el consuelo. Junto a Demófilo de Buen, Portela Valladares y Emilio Moret levantan las columnas de la logia Hispania «cuyo templo es el mismo que el de la Potencia Protectora: Rue Puteaux, 9" ${ }^{68}$. Cuando tienen todo arreglado mandan invitaciones a diversas logias francesas para que acudan a la instalación de los talleres: «Resueltos a propagar las doctrinas masónicas y a trabajar por el bien de la humanidad, tenemos la intención de fundar una Logia Simbólica en París bajo el título distintivo de Hispanias" ${ }^{69}$. La invitación iba firmada por Demófilo de Buen como Venerable Maestro, Carlos Esplá, como Orador y Emilio Moret en su calidad de Secretario Guarda-Sellos ${ }^{70}$. Durante los meses inmediatamente posteriores al final de la guerra civil, la vinculación de Esplá con la masonería se intensifica, pues vuelve a ser uno de los principales recursos a la hora de buscar apoyos para los refugiados españoles, tarea a la que se dedicará Esplá desde su llegada a Francia. Después, en México, donde estuvo afiliado a la Gran Logia de los Valles de México, Carlos Esplá dará otra vez muestras de independencia de criterio al negarse repetidas veces a satisfacer las demandas que, como miembro de la JARE, le solicitó el Gran Maestre Lucio Martínez Gil, pues suponían privilegiar la llegada de refugiados masones sobre otros que no lo eran ${ }^{71}$.

Carlos Esplá fue masón, y masón convencido, pero ni sus ideales ni sus actitudes tuvieron su origen en ese hecho. Cuando ingresó en la Orden ya estaba formado ideológicamente. Antes al contrario, la entrada de Carlos Esplá y de otros como él en la masonería en los años veinte, sirvió para inclinar la balanza a favor de aquellos que defendían su intervención en los asuntos políticos del país, transformándola en instrumento de lucha política en contra de la opinión de sus dirigentes. Cuando estos hombres llegaron al poder la Orden intentó influir en sus decisiones, algu-

\footnotetext{
68 Gomin Colomer, E., La Masonería en España. Madrid, 1944.

69 Ibídem.

70 lbídem.

71 Archivo Personal de Carlos Esplá. Correspondencia Lucio Martínez Gil-Carlos Esplá, 1941-42. En numerosas ocasiones Martínez Gil transmitió a Esplá la petición de que incluyese a determinados masones en los listados que elaboraba la JARE para traer refugiados de Francia a Méjico. En todas las ocasiones la respuesta de Esplá fue la misma: no podemos hacer excepciones con ningún refugiado, existe un reglamento y un procedimiento para elaborar los listados y a él hemos de remitirnos.
} 
nos obedecieron y otros no ${ }^{72}$. Carlos Esplá mantendría siempre su independencia de criterio, lo que no quiere decir que a veces su voto o sus acciones como gobernante coincidieran con algunas directrices masónicas, entre otras cosas porque en muchos puntos coincidían, por ejemplo en la importancia vital de la laicidad de la enseñanza.

En los años veinte y treinta había en la Orden, al menos, dos tipos de hermanos: aquellos que podríamos denominar, de forma simplista, masones republicanos y los republicanos masones, a este último grupo pertenecía Carlos Esplá. Para él ni la parafernalia, ni los ritos iniciaticos, ni las consignas emanadas de la jerarquía masónica tenían la más mínima importancia. Los talleres masónicos eran un lugar de encuentro con otros republicanos, un lugar para el intercambio de ideas en los momentos en que los partidos republicanos estaban en la clandestinidad; la masonería sería simplemente un instrumento, a veces eficaz, para combatir a la dictadura 0 , tras la guerra, para ayudar a los refugiados. Nada más ${ }^{73}$. Todo lo contrario se podría decir, por citar un caso opuesto, de Augusto Barcia, compañero de partido de Esplá y masón republicano. Para Barcia la Orden era algo más que un instrumento de lucha, era un credo y una liturgia, casi una religión, de ahí su oposición a que se inmiscuyera plenamente en los asuntos políticos, de los que pensaba podría salir muy dañada.

\section{PEQUEÑO APÉNDICE DOCUMENTAL}

«JESUITAS». Salvador Sellés. El Luchador, 1931. Alicante.

Ya vienen a bandadas los Hijos de Loyola:

siniestros y sombríos avanzan sin cesar:

Legiones son de negros espíritus que en ola

gigante se dilatan cual silencioso mar.

\footnotetext{
72 Ferrer Benimell, J.A., Masonería española contemporánea. Vol. 2, págs. 105 y ss. Afirma Ferrer que fueron muchas las circulares enviadas a los diputados masones por el Grande Oriente Español y por la Gran Logia de España, pidiendo que tuvieran en cuenta el programa masónico a la hora de elaborar el articulado de la Constitución. También dice que a la hora de votar el artículo 26, el 39,01 por ciento lo hicieron a favor y el 60,99 en contra, lo que demuestra que los diputados no siguieron al unísono las directrices de su respectiva Orden.

73 Por mucho que se busque en los miles de documentos que constituyen el Archivo Personal de Carlos Esplá, que por cierto está siendo digitalizado y pronto estará disponible para todos los investigadores que lo deseen en la Biblioteca Virtual Miguel de Cervantes de la Universidad de Alicante, no hay manera de encontrar referencia alguna a la masonería, si exceptuamos algunas anotaciones puramente anecdóticas.
} 
Ya tejen cautelosos la red de astuta guerra, a todo el que denuncia su hipócrita labor.

Ya acaparando ciegos de obcecación la tierra, no piensan en el Cielo, que fuera grande error.

¿Qué religión profesan con devoción impía? La religión del oro con su infernal poder, aunque Jesús les dice: "Mirad la vida mía: fui pobre, soy humilde: ¡Se dignos de mi ser!

No suspendais del pecho, de fe y amor desnudo, la imagen de mi triste y ensangrentada Cruz, ni alceis en vuestras luchas mi nombre por escudo contra los vivos dardos de mi Legión de luz.

Ved jay! que mientras todos con odio sanguinario de un mundo miserable pugnais por el laurel, el corazón me sangra convulso en mi Calvario, y me sofoca acerba la esponja de hiel».

¡Intransigencias rudas y cóleras sombrías ante el Progreso santo que espande luz de Dios! ¡Oh dulce y amoroso Jesús, ¿que les dirías?... ¡Todo eso no es cristiano, todo eso no sois Vos!

Decid, Señor, a falsos e infieles servidores que fingen tener alma de blanda condición, que dejen de ser duros e inicuos opresores de aquellos que profesan distinta religión.

Sabed que Dios permite las varias religiones: Sabed que Dios las quiere, pues las inspira al ser: No os opongais al Cielo con fieras rebeliones; no comenceis de nuevo la lid de Lucifer.

Las religiones todas elevan nuestra vida; quizá las más humildes a Dios conducen más De tantas religiones amad la preferida; mas es pasión injusta que odieis a las demás.

¿Quien sabe lo que esconde toda la conciencia ajena? ¡Oh Dios de los misterios, ¿quien sabe si sois Vos?. Escuche el fanatismo que a muerte nos condena: quien mata mil conciencias mil veces mata a Dios.

¿Y a quién amais vosotros los Hijos de Loyola? ¿Los fríos egoistas de dura condición? ¿A qué celestes fuegos vuestra alma se acrisola y en que divinas llamas os arde el corazón? 
Decís que vaís haciendo la paz en las conciencias; que vaís iluminando las mentes con la Cruz: ¿por qué esquivaros luego tras esas Residencias sombrías y cerradas al aire y la luz?

¿Por qué pisando quedos del rico las alfombras marchais al bien lo mismo que aquel marcha al mal, y vuestras obras buenas haceis entre las sombras como las obras malas perpetra el criminal?

¡Ah, no dejais vosotros el resplandor del astro detrás de vuestras plantas de huella tan sutil: dejais de negros odios un imborrable rastro; dejais desgarramientos de corazones mil!

Rompeis los tiernos lazos de la cordial familia, y haceis que se separe lo que juntó el Señor: Lo que infernais vosotros jamás se reconcilia: ¡Ya nunca a los hogares vuelve el perdido amor!

Decís taimadamente que el fin os justifica: ¿Qué fin es ese vuestro si no es acaparar? Mirad el pensamiento final que os santifica: Hacer un monte de oro y al mundo dominar!

No es el estéril Oro la Religión sagrada; la Religión divina, del hombre sumo Bien; Es la pobreza austera por el de Asis llamada Princesa real, diciendo a su hermosura: ven....

Yo vengo a revelaros una verdad sublime: Existe el Ser que un día vió en éstasis Amós: En vano en vuestra vida vuestra alma le suprime: ¡Hipócritas ateos! sabed que existe Dios!.

Fraguando sus maldades en negros escondrijos, ¡Oh España! los loyolas imperan hoy aquí:

Tus cátedras son suyas y suyos son tus hijos, que vuelven sus puñales en sombra contra ti.

Vuestra legión es pólipo multíplice en España: ¿A qué rincón no tiende su tentáculo el opresor? Y en lóbregas alturas sois la tremenda araña en cuya red sucumbre la Patria sin vigor.

Oh Patria, el negro monstruo de pústulas te llena. Imnumera y sombría te cubre esa legión; te oprime, te sofoca, te asfixia, te envenena... Ya Carlos el Tercero surgiendo te lo ordena: ¡Levántate gigante y exclama: La expulsión! 
«LA ESCUELA PARA EL POBRE». Carlos Esplá. El Luchador, 1925.

He leído en este Luchador de mis primeras luchas lo que ha dicho Marcelino

Domingo en Novelda. Me ha entusiasmado que haya puesto en ese acto la bomba de la escuela única. Han sido palabras magníficas las de Marcelino Domingo. Por la Escuela única ha de reñir la democracia europea una gran batalla. En España no había sido hasta ahora llevado este problema a la calle, no han gritado los pobre a los ricos su derecho a la escuela. Ha hecho bien Marcelino Domingo en abrir el fuego, en empezar a hablar en nombre de los desposeidos de la mejor riqueza.

El radicalismo francés ha hecho de la Escuela única un punto fundamental de su programa. Cuando el cristianismo de los banqueros puso sus fuerzas en juego para derribar a Herriot, empezó por atacar a su ministro de Instrucción Pública, a François Albert, viejo francés, ateo y humanista, menudo de cuerpo y grande ideas, a quien los reaccionarios temen como a un brujo. François Albert se había propuesto implantar en Francia la Escuela única, la escuela para todos, con acceso a la Universidad. Herriot sostuvo a su ministro contra todos los ataques de los conservadores, contra toda la chillería siniestra de discípulos de Berard y de Maurras, contra las mascaradas de los señoritos ricos del barrio Latino y las protestas hilarantes de las viejas aristócratas del faubourg Saint Germain. Herriot sostuvo a su ministro que llevaba en la cartera el proyecto de la Ecuela Unica. Y es que Herriot sabe lo que es ser estudiante pobre, lo que el hambre de pan y el hambre de libros. Herriot es de origen humildísimo. Su abuelo era pastor. Herriot pasó de la escuela al Lyceo porque ganó una beca. Toda su carrera universitaria la ha hecho como becario. Fue el número uno de su promoción estudiantil. Es uno de los hombres más cultos de Francia. Todo lo debe al Estado, que le abrió las puertas de la Universidad. Se comprende que Herriot ame a Francia. El patriotismo necesita también sus razones.

Antes de caer del Gobierno, Herrioi, François Albert y Painlevé hicieron una visita a sus antiguos condiscípulos. Ocuparon los mismos bancos que cuando eran estudiantes. Creo que ha sido esta ceremonia, poco conocida del público, la más importante y conmovedora que ha celebrado la República en muchos años.

El cristianismo de los banqueros arremetió contra Herriot porque este arremetía contra sus principios; la Universidad para la aristocracia del dinero podrá producir una minoría selecta que de la triste sensación de un estrafalario flautista recreándose con su música solitaria. La cultura de un pueblo no es un solo de flauta como ese que nos están dando los señores 
de la minoría selecta. La cultura de un pueblo la hace todo el pueblo. Empecemos por la Escuela Unica.

Esta será la gran obra de nuestra República de trabajadores y estudiantes. ¿La escuela para el pobre!. Es la forma de acabar con esta dramática injusticia de que haya pobres absolutamente pobres y ricos insultantemente ricos. Formaremos en la Escuela la generación que luego acabe con los demás privilegios. Es una obra que debemos empezar dentro de lo poco que podamos, de lo pobres que somos, los demócratas españoles. Debemos empezar por plantear el problema, por discutirlo, por no respetar ni el descanso eterno de esas viejas estúpidas que dejan sus riquezas a los jesuitas en vez de dejarlas para que los niños aprendan, debemos empezar por hacer nosotros algún sacrificio.

Nuestro gran problema empieza en la escuela. Mientras haya en España doce millones de analfabetos sin redención sufriremos todas las calamidades políticas, nos gobernarán analfabetos con pretensiones.....».

UN TEMPLO SIN DIOS. C. Esplá. EI Pueblo. Valencia, ¿1921?

\section{EI AGUA Y LA LIBERTAD}

"¡Fuentes y cuevas de Buñol! En el valle verde y húmedo, donde la Libertad es un jugo más de la tierra, se levantará un templo sin Diós, refugio de unos niños a quienes la Naturaleza robó la salud y los hombres el bienestar. Ante el publo liberal y acogedor nos hemos descubierto. Buñol es una manantial de ideas nobilísimas y la Libertad nace en el agua de sus fuentes, roja y deslumbradora como el sol, y en esas fuentes hemos apagado nuestra sed. El agua ha desterrado el fanatismo de Buñol, ha expulsado de aquellos parajes bellísimos al ejército negro, que vive en los pueblos sin agua y sin alegría, como los parásitos viven en los cuerpos sucios. ¡Fuentes y cuevas de Buñol! ¡Libertad!

\section{LAICISMO}

En Valencia, muchos centenares de niños llenas las aulas de las escuelas laicas, en una gloriosa liberación de la brutalidad religiosa. ¡Niños que son buenos sin el cruel y pavoroso temor del infierno!. Esas escuelas son la obra viva y eterna del republicanismo valenciano, de un partido que mira al porvenir y al que bastaría esta hermosa actividad para librarle de los defectos que le alcanzan como organización política.

Un maestro laico os dice:

-Llevo doce años en mi escuela y he educado a seis mil muchachos. 
Son los hombres laicos del mañana que han de arrancar de las conciencias la idea de Dios; son la futura generación republicana, llena de rebeldías y de ansia de Libertad. Cuando en las noches invernales veo los automóviles enormes, lujosos, iluminados de los jesuitas, de los maristas, cargados de niños ricos, recuerdo con amor nuestras pobres escuelas laicas donde germina una juventud libre y atea...

\section{NUESTRO TEMPLO}

Pero los niños pobres de nuestras escuelas laicas tendrán su templo, entre las fuentes y los árboles de Buñol. El pueblo admirable ha ofrecido el terreno como un regazo. Allí se levantará la Casa-colonia Blasco Ibáñez, como un templo de los hombres sin Dios, como un recuerdo vivo del creador del espíritu republicano en Valencia. El edificio costará cuarenta mil pesetas. Es deber del laicismo valenciano recogerlas cuanto antes. Un obrero de Buñol ha hecho su ofrecimiento: trabajar gratis todos los días de una semana en la Casa-colonia. Ante este ejemplo admirable ¿que pensarán hacer los hombres ricos de nuestro partido?.

\section{TOLERANCIA}

Los niños de las escuelas laicas y de todas las escuelas conviven y fraternizan en el descanso veraniego de las colonias. Han recibido el agua de Libertad de las fuentes de Buñol como un bautismo de tolerancia. Los niños que no oyen hablar de Dios en la escuela y los niños que rezan, cantan y ríen juntos, mientras la salud entre gozosa en los cuerpecitos débiles.

La religión no ha desencadenado todavía entre la sociedad infantil, tostada por el sol de las colonias, los terribles combates del fanatismo.... ¿Vivirán cuando sean hombres, esa amplia vida de tolerancia?

\section{ENVÍO}

A don Joaquín García Ribes y a don Mariano Pérez Feliu, dos hombres buenos y humildes, que levantan sobre sus hombros la obra magnífica del laicismo valenciano, con la misma gratitud de un niño a quien hubiesen arrancado en la escuela la idea de Dios....". 


\section{APAGANDO LAS LUMINARIAS DEL CIELO. C. Esplá. EI Pueblo, Valencia, 1921.}

Francia, durante la guerra, fue la más noble admiración de nuestra vida. Sus héroes, arrancados del taller y de la tierra, iban en marcha triunfal apagando las luminarias del cielo y los incendios del militarismo. Francia era la protesta contra Dios y contra el hurto de guerra. $Y$ cuando las notas eternas de La Marsellesa cantaron el Te-Deum de la Victoria, nos sentimos un poco defraudados porque continuaban encendidas las luminarias del cielo y de la guerra. Pero algunos destellos de Francia nos reconcilian con la nación Madre. Un destello reciente, una luminaria de libertad: en un pueblecito francés, un párroco, para conmemorar el heroísmo de algunos soldados del lugar, muertos en la guerra, inscribió sus nombres en una lápida, que fue colocada en la iglesia, y que terminaba así: ¡Rogad a Dios por ellos!

El padre de uno de aquellos héroes reclamó alegando que su hijo no había comulgado en la idea de aquel Dios, y el Tribunal Supremo de Francia obligó al párroco a borrar de la lápida el nombre del soldado laico, considerando la reclamación del padre como una defensa bien justificada de la libertad de conciencia.

¡Que admirable ejemplo de respeto para Dios y para el hombre! Nos une otra vez a nuestra Francia y hace brotar una nueva Marsellesa en los labios que besaron sus heridas.

El heroísmo laico de ese padre dolorido - que perdió su hijo por Francia, no por Dios - tal vez no sea comprendido por los españoles, que crean o dejen de creer en él, han de saludarle por la calle y tropezarse con él en cualquier momento de su vida. Yo no quiero encontrar a Dios en mi camino ni aun después de muerto; para eso he sacado mi cuerpo y mi conciencia de todos los templos y he apagado las luminarias de mi cielo. $Y$ me reventaría que, muerto de un tiro, de un botellazo ó del tifus, recomendase alguien que rogasen a Dios por mí. Dios no le haría caso y yo tampoco.

\section{FUENTES Y BIBLIOGRAFÍA}

\subsection{Archivos}

- Archivo personal de Carlos Esplá Rizo. Alicante. Este archivo, en proceso de digitalización para su inclusión íntegra en la Biblioteca Virtual Miguel de Cervantes de la Universidad de Alicante, guarda valiosa documentación sobre el exilio de posguerra, así como una nutrida 
correspondencia de Esplá con los principales dirigentes republicanos y socialistas. También recoge una extensa selección de los artículos publicados por Esplá a lo largo de su vida.

- Archivo de la Guerra Civil. Salamanca.

- Archivo de la Casa-Museo Miguel de Unamuno. Salamanca.

- Hemeroteca Muncipal de Alicante. Ayuntamiento de Alicante.

- Hemeroteca Municipal de Madrid. Madrid.

- Hemeroteca Provincial de Alicante. Biblioteca Pública. Alicante.

- Hemeroteca Nacional. Madrid.

\subsection{Bibliografía}

Andrés Gallego, J.: «La última evolución política de Castelar». Hispania, n. ${ }^{\circ} 115$. Madrid, 1970, págs. 385-393. "La III República francesa, la Restauración española y la Iglesia. Notas para una historia comparada»; en Historia Sacra, vol. XXXI-XXXIIl. 1978-79, págs. 323-339.

Al.calá Zamora, N.: Régimen político de convivencia en España. Buenos Aires, 1945.

Álvarez LAZARo, P.: Masonería y enseñanza laica durante la Restauración española; en Historia de la Educación. Tomo II. 1983.

Angosto VÉlez, P.L.: Carlos Esplá Rizo. Biografía Política. Tesis Doctoral dirigida por LA PARRA LÓPEZ, E. y leída el 2 de junio de 2000 en la Universidad de Alicante.

ApARici Díaz, A.: La escuela modelo de Alicante. Alicante, 1997.

Avilés FARRE, J.: La izquierda burguesa en la Segunda República. Espasa. Madrid, 1985.

Beltrán Reig, J.: La enseñanza en la ciudad de Alicante. Instituto de Estudios Alicantinos. Alicante, 1981.

COMIN COLOMER, E.: Lo que España debe a la masonería. Madrid, 1952.

- La masonería en España. Madrid, 1944.

Chevalier, P.: La separation de l'Eglise et de l'Ecole: Jules Ferry et Leon XIII. Fayard. París, 1981.

Díaz, E.: Filosofía social del krausismo. Fernando Torres, editor. Valencia, 1983.

DuARTE, A.: La esperanza repubicana, en CRuz, R. y PÉrez Ledesma, M.: Cultura y movilización en la España contemporánea. Alianza. Madrid, 1997.

FerRer Benimeli, J.A.: Masonería española contemporánea. Siglo XXI. Madrid, 1987.

- La masonería en la historia de España. Zaragoza, 1989.

- «La escuela laica lugar de enfrentamiento entre la Iglesia y la masonería (1868-1930); en Ecole et Eglise en Espagne et en Amerique Latine-Aspects ideologiques e institutionels. Tours, 1988.

GaRcía REGIDOR, T.: La polémica sobre la secularización de la enseñanza (1902-1914). Madrid, 1985.

Gómez MolledA, M.D.: La masonería en la crisis española del siglo xx. Taurus. Madrid, 1987.

GUTIÉRREZ LLORET, R.A.: El republicanismo en Alicante durante la Restauración. Ayuntamiento de Alicante. Alicante, 1989

La PARRA LóPez, E. y SuÁrez Cortina, M.: El anticlericalismo español contemporáneo. Biblioteca Nueva. Madrid, 1998.

MARICHAL, J.: El secreto de España. Taurus. Madrid, 1995.

NoEl, E.: Diario intimo. Taurus. Madrid, 1962.

Piqueras, J.A.y Chust, M. (eds.): Republicanismo y repúblicas en España. Madrid, 1996.

REnAN, E.: Vida de Jesús. Edaf. Madrid, 1985.

SUÁREZ CORTINA, M.: Anticlericalismo, religión y política en la Restauración, LA PARRA LÓPEZ, E. y SUÁREZ CORTINA, M.: El anticlericalismo español...

SÁnCHEZ MARTínEZ, G.: Guerra a Dios, a la tisis y a los reyes: Francisco Suñer y Capdevila, una propuesta materialista para la II mitad del siglo XIX. Ediciones UAM. Madrid, 1987.

Townson, N.: El republicanismo en España. 1830-1977. Madrid, 1994.

TUNNON DE LARA, M.: Medio siglo de cultura española, 1885-1936. Madrid, 1977.

ValíN Fernández, A.: Laicismo, educación y represión en la España del siglo xx. Ediciós do Castro. La Coruña, 1993.

VIDARTE, J.S.: Todos fuimos culpables. Méjico, 1973. 